\title{
Meristematic endodermis and secretory structures in adventitious roots of Richterago Kuntze (Mutisieae-Asteraceae)
}

\author{
GLADYS F.A. MELO-DE-PINNA ${ }^{1,3}$ and NANUZA L. MENEZES ${ }^{2}$
}

(received: December 13, 2000; accepted: August 14, 2002)

\begin{abstract}
Meristematic endodermis and secretory structures in adventitious roots of Richterago Kuntze (MutisieaeAsteraceae)). The meristematic endodermis in adventitious roots of Richterago species originates in one of the fundamental meristem cells, which undergo sucessive anticlinal and periclinal divisions to build the inner cortex. The meristematic endodermis or proendodermis remains as a meristematic layer until its differentiation into endodermis, with Casparian strip. When sieve elements differentiate, endodermic secretory canals of esquizogenous origin are present at the region adjacent to primary phloem. Articulated laticifers, with cells perforated at both terminal and transversal walls, also occur during initial phases of secondary development. Presence of inulin as reserve carbohydrate in the inner cortex and vascular tissue may be related to abiotic factors, as an adaptive strategy of these species.
\end{abstract}

Key words - Asteraceae, laticifers, meristematic endodermis, Richterago, secretory canals

RESUMO - (Endoderme meristemática e estruturas secretoras em raízes adventícias de Richterago Kuntze (MutisieaeAsteraceae)). Nas raízes adventícias de espécies de Richterago, a endoderme meristemática origina-se a partir de uma das células do meristema fundamental, que irá sofrer sucessivas divisões anticlinais e periclinais para formar o córtex interno, permanecendo como uma camada meristemática até sua diferenciação em endoderme com as estrias de Caspary. Quando os elementos crivados já se encontram diferenciados, canais secretores endodérmicos, de origem esquizógena, podem ser visualizados nas regiões adjacentes ao floema primário. Laticíferos articulados ocorrem na fase inicial do desenvolvimento secundário, cujas células apresentam pontoações nas paredes terminais e transversais. A presença de inulina no córtex interno e no cilindro vascular, como carboidrato de reserva, pode estar relacionada com fatores abióticos, sendo uma estratégia adaptativa das espécies.

Palavras-chave - Asteraceae, canais secretores, endoderme meristemática, laticíferos, Richterago

\section{Introduction}

The occurrence of a meristematic phase of endodermis in Asteraceae was first demonstrated by Williams (1947). That author demonstrated that the cellular layer, which surrounds the plerome (pericycle), acts as a cambium generating the cortex, which later will differentiate into endodermis. Subsequent to Williams's paper, a considerable amount of work (Hurst 1956 apud Van Fleet 1961, Van Fleet 1961, Mueller 1991, Seago Júnior et al. 1999, Seago Júnior et al. 2000) recognised meristematic endodermis in the root's of other vascular plants.

From the second half of the $19^{\text {th }}$ century, many authors have studied secretory structures in Asteraceae

\footnotetext{
1. Universidade Federal de Pernambuco, Centro de Ciências Biológicas, Departamento de Botânica, Av. Prof. Moraes Rêgo s/n, Cidade Universitária, 50632-970 Recife, PE, Brasil.

2. Universidade de São Paulo, Instituto de Biociências, Departamento de Botânica, Rua do Matão, Travessa 14. Cidade Universitária, 05422-970 São Paulo, SP, Brasil.

3. Corresponding author: gfmelopinna@aol.com
}

(Tetley 1925). The intercellular canals and laticifers are features recognized in this family (Col 1899, 1901, 1903, 1904, Tetley 1925, Williams 1947, 1954, Metcalf \& Chalk 1950, Esau 1960, Fahn 1974, Heywood 1978, Bremer 1994). In roots, secretory canals may occur in the inner cortex (Col 1899, Triebel 1885, Solereder 1908, Tetley 1925, Williams 1947, 1954, Lersten \& Curtis 1986, Luque et al. 1997), pericycle (Grotta 1944, Hoehne et al. 1952) and phloem (Metcalf \& Chalk 1950, Grotta 1944). Nevertheless, no studies so far have focused on root secretory canals species of the tribe Mutisieae.

The genus Richterago Kuntze belongs to the tribe Mutisieae and is endemic to Brazil. The present work focuses on morphoanatomic features of its adventitious roots, with emphasis on the occurrence of meristematic endodermis and secretory structures.

\section{Material and methods}

Eleven species of Richterago were studied: R. stenophylla Cabrera, R. angustifolia (Gardner) Cabrera, 
$R$. arenaria (Baker) Roque, $R$. radiata (Vell.) Cabrera, $R$. polymorpha (Less.) Cabrera, R. conduplicata Roque, $R$. hatschbachii Zardini, R. polyphylla (Baker) Roque, $R$. riparia Roque, $R$. amplexifolia and $R$. lanata Roque, all collected at Serra do Cipó, Santana do Riacho country (Minas Gerais-Brazil). Material is deposited in the herbarium of Universidade de São Paulo, SPF (Roque et al. 347, Roque et al. 352, Melo et al. 19, Melo \& Vitta 4, Melo et al. 15, Melo \& Vitta 10, Roque et al. 345, Roque et al. 450, Roque \& Hervêncio 493, Melo \& Vitta 8 and Melo et al. 12).

The primary root apex and adventitious roots were obtained from wild-collected young plants fixed in FGAA (Lersten \& Curtis 1988). After dehydration in graded ethanol series, the material was preserved in $70 \%$ ethanol and embedded in paraffin (Johansen 1940). The material was double-stained with Astra blue and basic fucsin, following Kraus et al. (1998). Dissociation technique with hydrogen peroxide and acetic acid (Franklin 1945) was used to analyze the laticifers.

The following stains were used for histochemical tests: Sudan IV (Sass 1951); 10\% ferric chloride (Johansen 1940) and lugol (Berlyn \& Mikche 1976), for lipidic substances, phenolic substances and starch, respectively. The technique described by Purvis et al. (1964) was utilized to crystallize inulin with $100 \%$ ethanol for 48 hours.

\section{Results}

The rootcap generated by calyptrogen was observed at the region of subapical meristem in adventitious roots (figures 1-2). Protoderm, ground meristem and procambium originated in the promeristem. Ground meristem generated the proendodermis or meristematic endodermis through longitudinal (tangential) divisions, creating many rows.

On transverse section of the meristematic region, the meristematic endodermis is distinguishable from the pericycle, due to morphoanatomical difference between cells (figures 3-5). A thickening on the contact walls between the meristematic endodermis and the pericycle cells was also observed (figure 6). Meristematic activity of the inner layer of the cortex shows cytoplasmic gradient characterized by the vacuole enlargement in the derivative cells, if compared to cells closer to the meristematic endodermis (figure 3 ). Over subsequent stages, cells resultanting from the meristematic endodermis will be arranged radially, forming the inner cortex (figures 3,4).

At this stage, secretory canals are seen at innermost layers of the cortex, originated by an esquizogenous process, and restricted to regions adjacent to the phloem (figure 5). After meristematic activity of the proendodermis, the innermost layer of the cortex will differentiate in endodermis with deposition of Casparian strips in anticlinal walls. In innermost canals, endodermal cells with Casparian strips constitutes two of the four cells underlying the canal. The contents of secretory canals react positively to phenolic substances, carbohydrates and lipids.

During initial phase of differentiation, sieve tube elements are clearly observed on transverse section (figure 5). At subsequent stages, protoxylem differentiation initiates.

The radial arrangement of the cells generated by meristematic endodermis is shown in figure 4 . Intercellular spaces are present closer to the exodermis, forming cavities. In Richterago arenaria and $R$. stenophylla, sclereids were present within the entire cortical region (figure 7). At the outer cortical region, cells contaning lipidic droplets were observed (figure 8). The pericycle is located internally to the endodermis and it may be biseriated or triseriated inwardly (figure 9). The radial arrangement of innermost layers of the cortex becomes less evident at advanced stages of the secondary structure (figures 10, 11).

Articulated laticifers at the cortex with perforation fields on transverse and terminal walls were observed (figures 12-14). Inulin content is observed in the inner cortex cells, including endodermis (figure 15), in the pericycle and in xylem cells. Phloem parenchyma cells also contain inulin. Inulin crystals, when analyzed under polarized light, form Malta crosses (figures 16, 17).

\section{Discussion}

Williams (1947) discussed the occurrence of a cellular layer which surrounds the tissue he called plerome which later differentiates into endodermis. The author states this layer acts as a cambium, generating every tissue between endodermis and hypodermis in the primary body of the roots. This meristematic phase of the endodermis was called proendodermis by Hurst (1956 apud Van Fleet 1961), even though Van Fleet (l.c.) and Williams (1947) had previously refered to it as "meristematic endodermis". The term proendodermis has been used by several authors (Mueller 1991, Seago Júnior et al. 1999, Seago Jr. \& Scholey 1999, Seago Júnior et al. 2000), who described it as a layer derived from an initial cell of the ground meristem, located near the procambium and which would differentiate into endodermis. These features have been found in species of Richterago, especially the meristematic role of the 


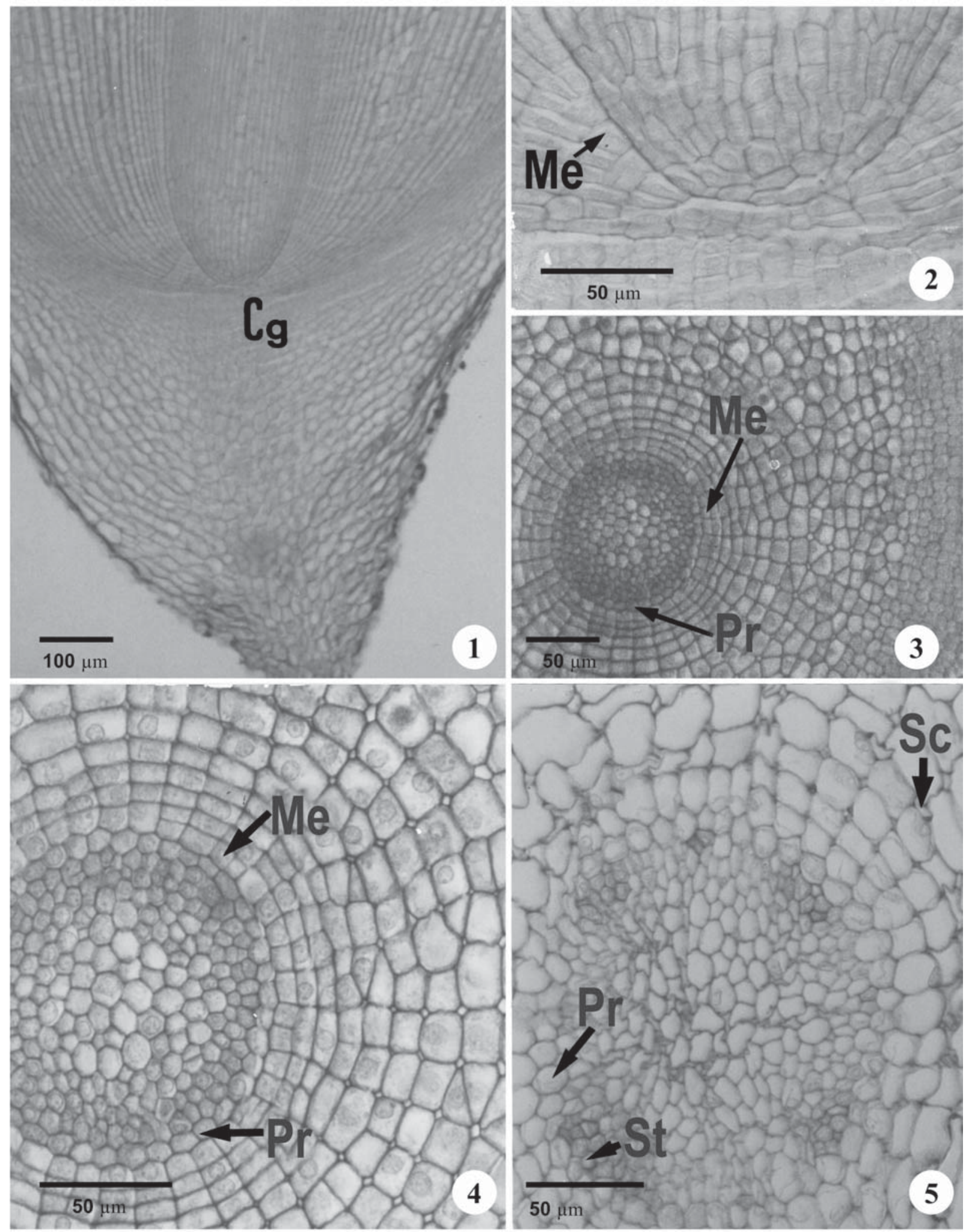

Figures 1-5. Region of the sub-apical meristem in adventitious roots of Richterago arenaria. 1. Longitudinal section, showing the rootcap generated by the caliptrogen. 2. Detail of the meristematic region showing meristematic endodermis. 3 . Transverse section, showing a radial row of cortical cells originated from the meristematic endodermis. 4. Close up of figure 3 showing cells of the meristematic endodermis in division. 5. Transverse section $200 \mu \mathrm{m}$ proximal to figure 4 , showing the secretory canals. $(\mathrm{Cg}=$ calyptrogen; $\mathrm{Me}=$ meristematic endodermis; $\mathrm{Pr}=$ pericycle; $\mathrm{St}=$ sieve tube element; $\mathrm{Sc}=$ secretory canals $)$. 


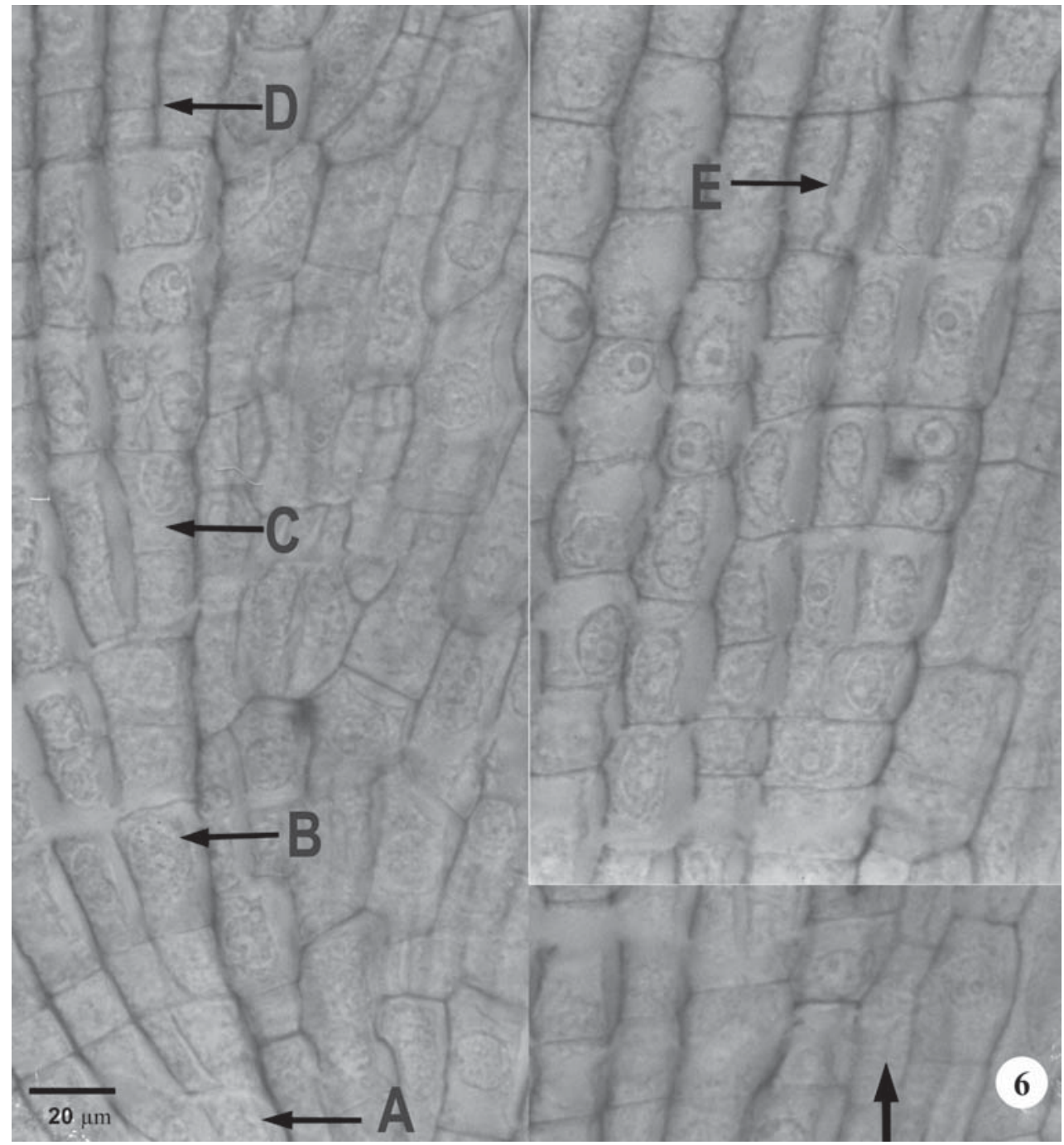

Figure 6. Longitudinal section of the subapical meristem region in adventitious root of Richterago arenaria. Arrows A-E, divisions from a single cell of the meristematic endodermis.

inner layer of the cortex, which differentiates into endodermis.

The organization of secretory structures in Asteraceae has been extensively studied by Col (1899, 1901, 1903, 1904). Three types of organization in secretory structures of Asteraceae have been recognized by that author: anastomosed laticifers, secretory canals and isolated cells, which secrete latex. Col also recognized two distinct types of secretory canals: the secretory canal itself, which is always formed near the endodermis, and secretory purses, which are wider and shorter than the canals, and have their cavity surrounded by secretory cells. These purses differ from the canals only in size.

Tetley (1925) described two types of secretory canals: endodermic and non-endodermic. According to him, endodermal secretory canals may be surrounded by four epithelial cells. Nevertheless, in most cases, these cells keep dividing originating 10 epithelial cells, as in the case of Buphthalmum speciosum (Tetley 1925). Endodermal secretory canals are present in the region of cells derived from meristematic endodermis in Richterago species, but the epithelial cells do not divide and the canal is limited by four cells only.

Papers that demonstrate the endodermis participation in the formation of secretory canals include Solereder (1908), Tetley (1925), Guttemberg (1968) and Luque et al. (1997). According to Solereder (l.c.), endodermic cells divide forming biseriated region and secretory canals through an esquizogenous process. Guttenberg (1968) describes the ontogeny of secretory 


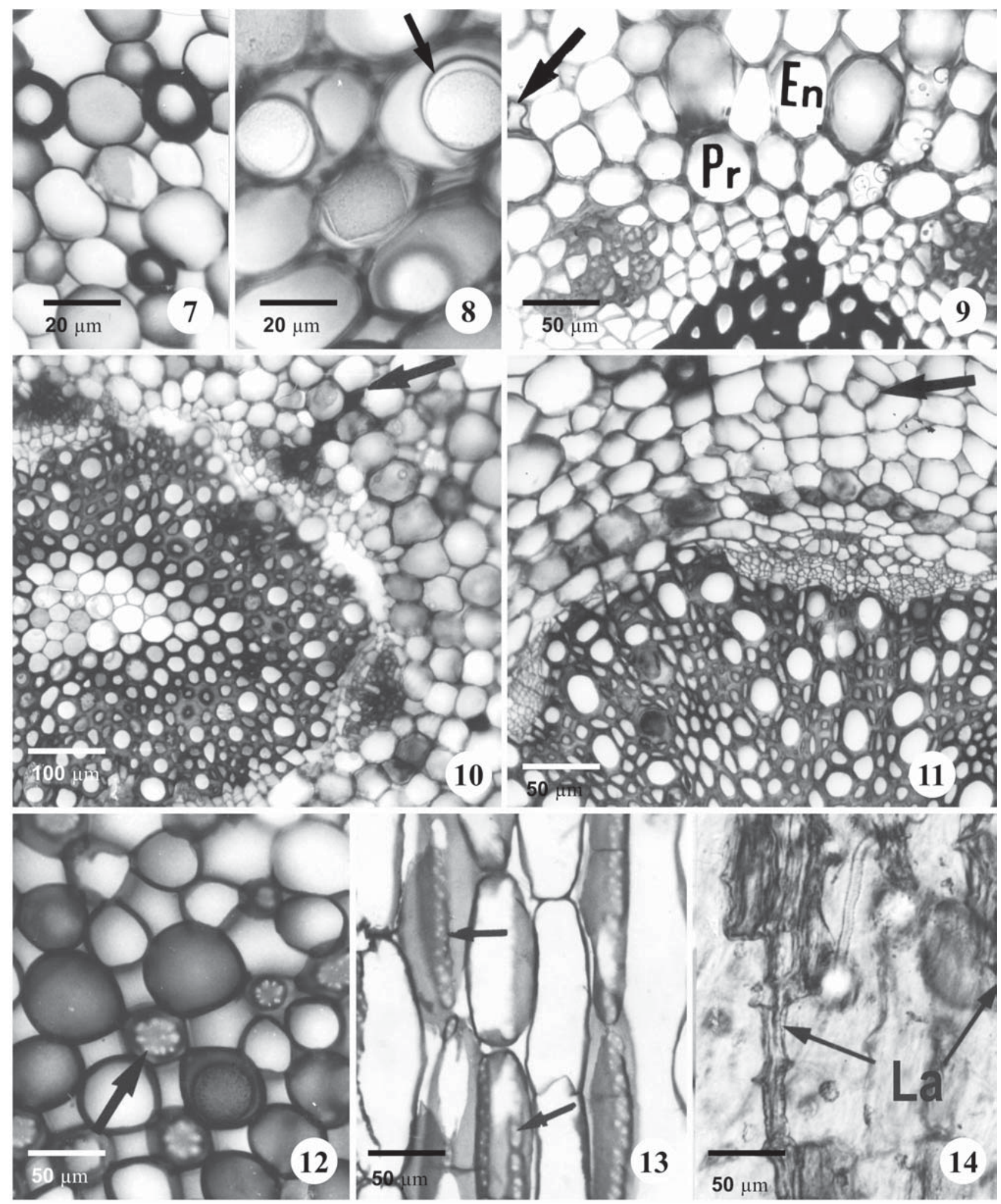

Figures 7-14. 7. Transverse section of Richterago stenophylla, showing intercellular spaces and the sclereids. 8. Richterago riparia, cortical cells containing lipidic drops (arrow). 9. Richterago lanata, endodermal cells making up two of those four cells of the secretory canal (arrow). 10-11. Transverse sections of the roots of $R$. polyphylla, showing endodermic scretory canals (arrows). 12-14. Richterago lanata. 12. Transverse section showing articulated laticifers at the cortex (arrow). 13. Longitudinal section of the cortical region, showing laticifer cells with perforation fields on transverse and terminal walls (arrows). 14. Articulated laticifers observed after dissociation technique. $(\mathrm{En}=$ endodermis; $\mathrm{Pr}=$ pericycle; $\mathrm{La}=$ laticifers $)$. 
canals in Asteraceae, from one endodermic mother cell, which undergoes divisions forming two cell layers. This fact was confirmed by Luque et al. (1997) on Lychnophora studied species.

A survey of works on species of the family Asteraceae (table 1) shows that the 42 studied species include good representation of the subfamilies Asteroideae and Cichorioideae, but no records of the subfamily Barnadesioideae. So far, the only reference to secretory canals in Mutisieae are for the genera Richterago (present paper) and Ianthopappus (Melo-de-Pinna 2000). Secretory canals occur on the inner cortex and phloem, but they may also occur internally to the endodermis, associated with the pericycle, and have been recorded in two species of the tribe Heliantheae (Grotta 1944, Hoehne et al. 1952). In Spilanthes acmella, Grotta (1944) observed that secretory canals appear in the parenchyma of secondary phloem as the root grows.
Some authors have suggested that secretory canals and primary phloem constitute a morphological unity in which the canals help the sieve tube elements on the conduction of metabolites (Solereder 1908, Guttenberg 1968, Williams 1947, 1954). Secretory canals in the primary phloem have not been observed in Richterago.

Tetley (1925) assumed that the contents of the canals come from the phloem, because they are formed when the first sieve elements are already distinguishable. That author also suggests that secretion is generated in the phloem and passes through the radial walls of the cell which subsequently differentiates in endodermis. The three species of Lychnophora studied by Luque et al. (1997) lack indication that secretory canals were aiding phloem on the conduction of metabolites. Nevertheless, histochemical tests revealed contents of the same nature in endodermal canals and phloem cells. Physiological studies must proceed in association with histochemical and ultrastructural
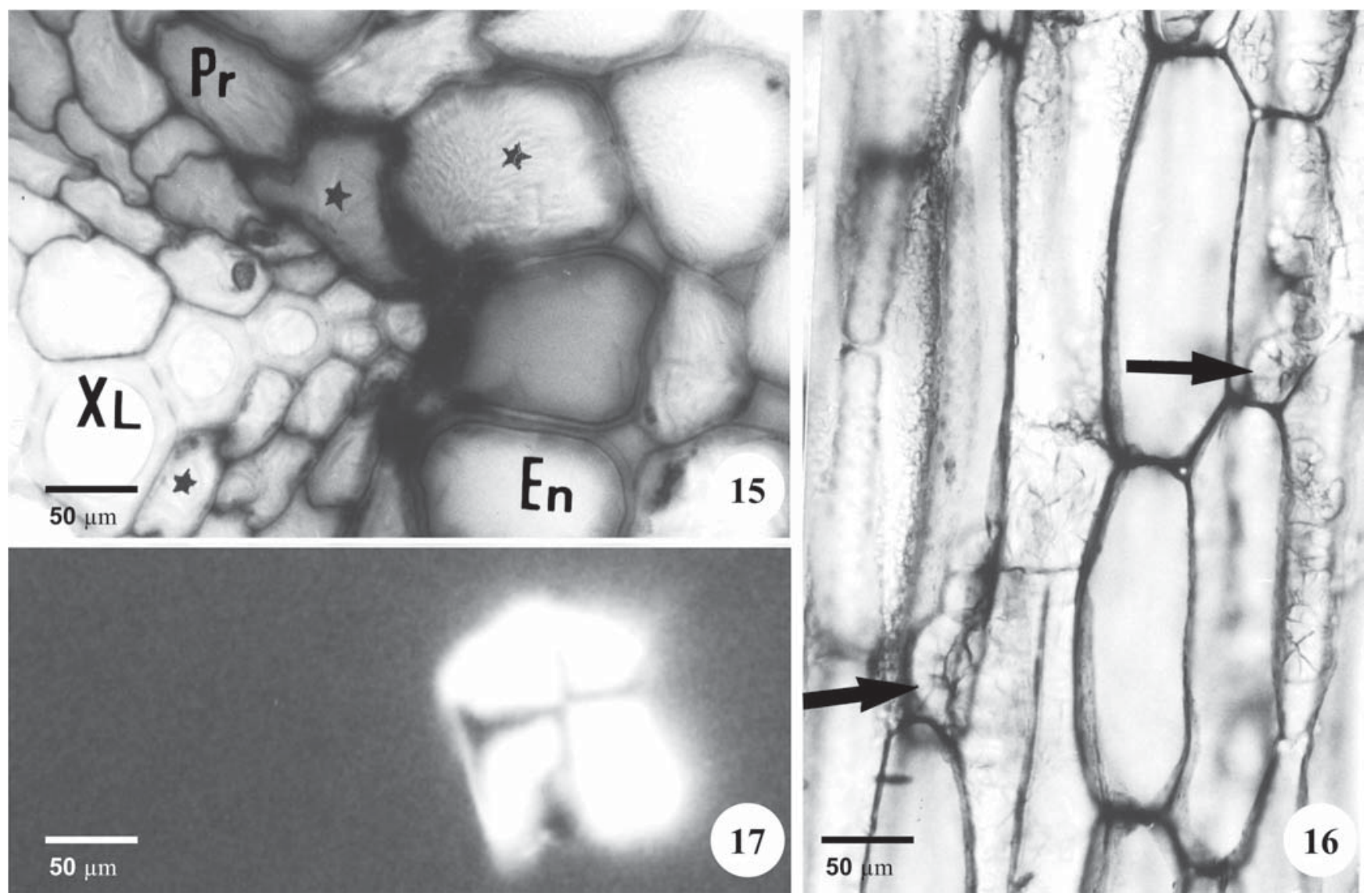

Figures 15-17. 15. Richterago hatschbachii, transverse section showing cortex, pericycle and xylem cells containing inulin (asterisk). 16. Richterago conduplicata, longitudinal section showing crystal of inulin (arrows). 17. Crystal of inulin when analyzed under polarized light, forming Malta crosses. $(\mathrm{XL}=$ xylem; $\mathrm{En}=$ endodermis; $\mathrm{Pr}=$ pericycle $)$. 
Table 1. Species of the Asteraceae studied listed the tribes and the position of the secretory canals in the roots.

\begin{tabular}{|c|c|c|}
\hline $\begin{array}{l}\text { Tribe } \\
\text { Species }\end{array}$ & Position of the secretory canals & References \\
\hline \multicolumn{3}{|l|}{ ANTHEMIDEAE } \\
\hline Anacyclus spp. & Phloem & Metcalfe \& Chalk (1950) \\
\hline \multicolumn{3}{|l|}{ ASTEREAE } \\
\hline Aster spp. & Inner córtex & Williams (1954) \\
\hline Solidago spp. & Inner córtex & Williams (1954) \\
\hline Erigeron spp. & Inner córtex & Williams (1954) \\
\hline Erigeron canadensis L. & Inner cortex & Williams (1947) \\
\hline \multicolumn{3}{|l|}{ CARDUEAE } \\
\hline Cirsium spp. & Inner cortex & Williams (1954) \\
\hline Carlina spp. & Phloem & Metcalfe \& Chalk (1950) \\
\hline Centaurea spp. & Phloem & Metcalfe \& Chalk (1950) \\
\hline Carthamus spp. & Phloem & Metcalfe \& Chalk (1950) \\
\hline \multicolumn{3}{|l|}{ EUPATORIEAE } \\
\hline Eupatorium spp. & Inner cortex & Williams (1954) \\
\hline Mikania spp. & Inner cortex & Williams (1954) \\
\hline Eupatorium perfoliatum L. & Inner cortex & Williams (1947) \\
\hline Eupatorium rugosum Spreng. & Inner cortex & Lersten \& Curtis (1986) \\
\hline \multicolumn{3}{|l|}{ HELENIEAE } \\
\hline Helenium spp. & Inner cortex & Williams (1954) \\
\hline Helenium spp. & Phloem & Tetley (1925) \\
\hline Tagetes spp. & Inner cortex & Williams (1954) \\
\hline Tagetes erecta $\mathrm{L}$. & Inner cortex & $\begin{array}{l}\text { Van Tieghem (1870/71, } \\
\text { apud Guttemberg 1968) }\end{array}$ \\
\hline \multicolumn{3}{|l|}{ HELIANTHEAE } \\
\hline Coreopsis spp. & Inner cortex & Williams (1954) \\
\hline Cosmos spp. & Inner cortex & Williams (1954) \\
\hline Bidens spp. & Inner cortex & Williams (1954) \\
\hline Silphium spp. & Inner cortex & Williams (1954) \\
\hline Helianthus spp. & Inner cortex & Williams (1954) \\
\hline Verbesina spp. & Inner cortex & Williams (1954) \\
\hline Xanthium canadensis Mill. & Inner cortex & Williams (1947) \\
\hline Rudbeckia lacinata $\mathrm{L}$. & Inner cortex & Williams (1947) \\
\hline Dahlia imperialis Roezl. & Inner córtex & Williams (1947) \\
\hline Bidens pilosa $\mathrm{L}$. & Inner córtex & Duarte (1997) \\
\hline Galinsoga parviflora Cav. & Inner córtex & Duarte (1997) \\
\hline Galinsoga ciliata (Raf.) Blake & Inner cortex & Duarte (1997) \\
\hline Spilanthes acmella L. & Pericycle and secondary phloem & Grotta (1944) \\
\hline Calea pinnatifida Banks & Pericycle & Hoehne et al. (1952) \\
\hline Dahlia variabilis Benth. \& Hook & Inner cortex & $\begin{array}{l}\text { Mager (1932 } \\
\text { apud Guttemberg 1968) }\end{array}$ \\
\hline Dahlia spp. & Phloem & Metcalfe \& Chalk (1950) \\
\hline \multicolumn{3}{|l|}{ INULEAE } \\
\hline Inula spp. & Phloem & Metcalfe \& Chalk (1950) \\
\hline Inula spp. & Phloem & Tetley (1925) \\
\hline \multicolumn{3}{|l|}{ MUTISIEAE } \\
\hline Richterago radiata (Vell.) Cabrera & Inner cortex & Present paper \\
\hline Richterago arenaria (Baker) Roque & Inner cortex & Present paper \\
\hline Richterago polymorpha (Less.) Cabrera & Inner cortex & Present paper \\
\hline Richterago polyphylla (Baker) Roque & Inner cortex & Present paper \\
\hline Richterago stenophylla Cabrera & Inner cortex & Present paper \\
\hline
\end{tabular}


(cont.)

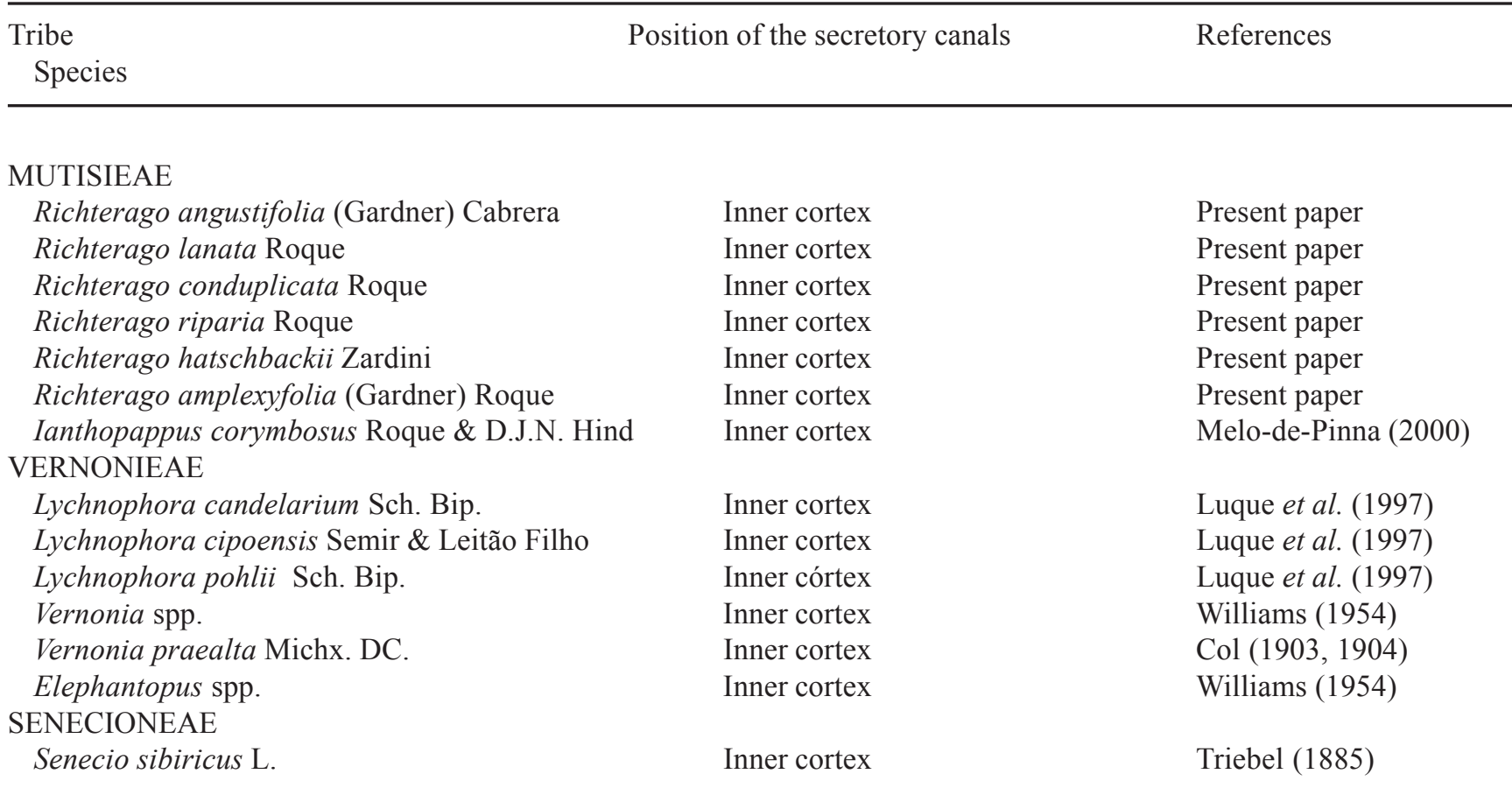

studies in order to elucidate a possible functional relationship between these canals and the phloem.

According to Solereder (1908), latex-secreting cells may be associated with phloem, endodermis or fibers and, when within the cortex, may be either isolated or in linear series. Datta \& Iqbal (1994) suggested that articulated laticifers may be simply interconnected by plasmodesmata; either through perforations on terminal walls or by their complete absorption. For Asteraceae, Vertrees \& Mahlberg $(1975,1978)$ described the presence of articulated laticifers with perforations on terminal walls in Cichorium intybus. Richterago species have articulated laticifers in linear series not associated with the endodermis. These laticifers have perforations on both terminal and transversal walls, in contrast to the condition described by Vertrees \& Mahlberg $(1975,1978)$.

The carbohydrate reserve detected through histochemical tests in the roots of Richterago is only inulin. Starch grains and other polysaccharides have not been detected. Some works have emphasized the occurrence of inulin in species of the family Asteraceae (Figueiredo-Ribeiro et al. 1986, Blocklebank \& Hendry 1989, Felipe \& Dale 1990, Isejima \& FigueiredoRibeiro 1991, Tertuliano \& Figueiredo-Ribeiro 1993). According to Tertuliano \& Figueiredo-Ribeiro (1993), in species of Asteraceae, crystals of inulin occur in cells from the parenchyma associated or not with vascular bundles. The authors do not report inulin in species of the tribe Mutisieae, although they have detected its presence in two species of Gochnatia (G. barrosii and G. pulchra).

Inulin is associated with the secondary xylem and, in minor amounts, with the medullary parenchyma of Viguiera discolor (Isejima \& Figueiredo-Ribeiro 1991). In Microseris lanceolata (Incoll et al. 1989) and Helianthus tuberosus (Soja et al. 1989), inulin is associated with the secondary phloem. The Richterago species studied in this work have the same pattern of inulin distribution recorded in species of the tribes Heliantheae and Eupatorieae, i.e., cortical parenchyma, pericycle and axial parenchyma of xylem and phloem.

According to some authors (Blocklebank \& Hendry 1989, Felipe \& Dale 1990, Isejima \& FigueiredoRibeiro 1991), fructans have functions other than that of energy source or reserve carbohydrate, and are also related to environmental stress tolerance, especially in savannas, as an adaptive strategy to the dry season. Richterago species studied occur in the campos rupestres, where abiotic factors like fire, low water availability in the soil and high temperatures all may affect the metabolism of these plants, and so inulin reserve might represent an adaptive strategy. 
Acknowledgments - The authors thank Coordenadoria de Aperfeiçoamento de Pesquisa (Capes) and Fundação de Amparo à Pesquisa do Estado de São Paulo (Fapesp / Proc. 1997/0493-2) for funding; We are grateful to M.E.M. Estelita for discussions about laticifers.

\section{References}

BERLYN, G.P. \& MIKSCHE, J.P. 1976. Botanical microtechnique and cytochemistry. Iowa State University Press, Ames.

BREMER, K. 1994. Asteraceae. Cladistic \& Classification. Timber Press, Portland.

BROCKLEBANK, K.J. \& HENDRY, G.A. 1989. Characteristics of plant species which store different types of reserve carbohydrates. The New Phytologist 112:255-260.

COL, M. 1899. Quelques recherches sur l'appareil sécréteur des Composées. Journal de Botanique 13:234-252.

COL, M. 1901. Quelques recherches sur l'appareil sécréteur des Composées. Journal de Botanique 15:166-168.

COL, M. 1903. Recherches sur l'appareil sécréteur interne des Composées. Journal de Botanique 17:288-318.

COL, M. 1904. Recherches sur l'appareil sécréteur interne des Composées. Journal de Botanique 18:153-175.

DATTA, S.K. \& IQBAL, M. 1994. The laticiferous system in vascular plants. In Growth patterns in vascular plants. (M. Iqbal, ed.). Dioscorides Press, Oregon.

DUARTE, M.R. 1997. Caracteres anatômicos de Bidens pilosa L., Galinsoga prviflora Cav. e G. ciliata (Raf.) Blake, Asteraceae. Tese de doutorado, Universidade de São Paulo, São Paulo.

ESAU, K. 1960. Anatomy of seed plants. Wiley International Edition, New York.

FAHN, A. 1974. Plant anatomy. $2^{\text {nd }}$ ed. Pergamon Press, Oxford.

FRANKLIN, G.L. 1945. Preparation of thin sections of synthetic resins and wood-resin composites, and a new macerating method for wood. Nature 155:51.

FELIPE, G.M. \& DALE, J.E. 1990. The effects of phosphate supply on growth of plants from the Brazilian Cerrado: experiments with seedlings of the annual weed, Bidens gardneri Baker (Compositae) and the tree, Qualea grandiflora (Mart.) (Vochysiaceae). Oecologia 82:81-86.

FIGUEIREDO-RIBEIRO, R.C.L., DIETRICH, S.M.C., CHU, E.P., CARVALHO, M.A.M., VIEIRA, C.C.J. \& GRAZIANO, T.T. 1986. Reserve carbohydrates in underground organs of native Brazilian plants. Revista Brasileira de Botânica 9:159-166.

GROTTA, A.S. 1944. Contribuição ao estudo morfológico e anatômico de Spilanthes acmella L. (Compositae). Anais da Faculdade de Farmácia e Odontologia da USP 4:130-164.

GUTTENBERG, H. 1968. Der primäre Bau der Angiospermenwurze. Handbuch der Pflanzenatomie (K. Lindsbauer, ed.). Gebruder Borntraeger, Berlin, p.233-257.
HEYWOOD, V.H. 1978. Flowering plants of the world. Oxford University Press, Oxford.

HOEHNE, W., GROTTA, A.S. \& SCAVONE, O. 1952. Contribuição ao estudo morfológico e anatômico de Calea pinnatifida Banks. Anais da Faculdade de Farmácia e Odontologia da USP 10:9-33.

INCOLL, L.D., BONNERR, G.D. \& GOTT, B. 1989. Fructans in the underground storage organs of some Australian plants used for food by Aborigines. Journal of Plant Physiology 134:196-202.

ISEJIMA, E.M. \& FIGUEIREDO-RIBEIRO, R.C.L. 1991. Fructan composition in adventitious tuberous roots of Vigueira discolor Baker (Asteraceae) as influenced by daylength. The New Phytologist 119:149-154.

JOHANSEN, D.A . 1940. Plant microtechnique. McGrawHill Book Co., New York.

KRAUS, J.E., SOUSA, H.C., REZENDE, M.H., CASTRO, N.M., VECCHI, C. \& LUQUE, R. 1998. Astra blue and basic fucsin double staining of plant materials. Biotechnic \& Histochemistry 73:235-243.

LERSTEN, N.R. \& CURTIS, J.D. 1986. Tubular cavities in white snakerrot, Eupatorium rugosum (Asteraceae). American Journal of Botany 73:1016-1021.

LERSTEN, N.R. \& CURTIS, J.D. 1988. Secretory reservois (ducts) of two kinds in giant ragweed (Ambrosia trifida; Asteraceae). American Journal of Botany. 75:1313-1323.

LUQUE, R., MENEZES, N.L. \& SEMIR, J. 1997. La función secretora de la endodermis de la raíz de especies de Lychnophora Mart. (Asteraceae). Plantula 1:221-228.

MELO-DE-PINNA, G.F.A. 2000. Anatomia dos órgãos vegetativos dos gêneros Richterago Kuntze e Ianthopappus Roque \& D.J.N. Hind (MutisieaeAsteraceae). Tese de doutorado, Instituto de Biociências, Universidade de São Paulo, São Paulo.

METCALFE, C.R. \& CHALK, L. 1950. Anatomy of the Dicotyledons: leaves, stern and wood in relation to taxonomy with notes on economic uses. Claredon Press, Oxford. v.2.

MUELLER, R.J. 1991. Identification of procambium in the primary root of Trifolium pratense (Fabaceae). American Journal of Botany 78:53-62.

PURVIS, M.J., COLLIER, D.C. \& WALLS, D. 1964. Laboratory techniques in botany. Butterworths. London.

SASS, J.E. 1951. Botanical microtechnique. Iowa State College Press, Ames.

SEAGO JR., J.L., PETERSON, C.A. \& ENSTONE, D.E. 1999. Cortical ontogeny in roots of the aquatic plant, Hydrocharis morsus-ranae L. Canadian Journal of Botany 77:113-121.

SEAGO JR., J.L. \& SCHOLEY, A. 1999. Development of the endodermis and hypodermis of Typha glauca Gord. and Typha angustifolia L. roots. Canadian Journal of Botany 77:122-134. 
SEAGO JR., J.L., PETERSON, C.A. \& ENSTONE, D.E. 2000. Cortical development in roots of the aquatic plant Pontederia cordata (Pontederiaceae). American Journal of Botany 87:1116-1127.

SOJA, G., HAUNOLD, E. \& PRAZNIK, W. 1989. Translocation of ${ }^{14} \mathrm{C}$-assimilates in Jerusalem artichoke (Helianthus tuberosus). Journal of Plant Physiology 134:218-223.

SOLEREDER, H. 1908. Systematic anatomy of dicotyledons. Clarendon Press, Oxford.

TERTULIANO, M.F. \& FIGUEIREDO-RIBEIRO, R.C.L. 1993. Distribution of fructose polymers in herbaceous species of Asteraceae from the cerrado. The New Phytologist 123:741-749.

TETLEY, U. 1925. The secretory system of the roots of the Compositae. The New Phytologist 24:138-161.
TRIEBEL, R. 1885. Ueber Oelbehälter in Wurzeln von Compositen. Nova Acta der Leopold-Carol. Deutschen Akademic der Naturforscher 1:1-45.

VAN FLEET, D.S. 1961. Histochemistry and function of the endodermis. Botanical Review 27:165-220.

VERTREES, G.L. \& MAHLBERG, P.G. 1975. Nuclei in laticifers of Cichorium intybus. Phytomorphology 25:282-288.

VERTREES, G.L. \& MAHLBERG, P.G. 1978. Structure and ontogeny of laticifers in Cichorium intybus (Compositae). American Journal of Botany 65:764-771.

WILLIAMS, B.C. 1947. The structure of the meristematic root tip and origin of the primary tissues in the roots of vascular plants. American Journal of Botany 34:455-462.

WILLIAMS, B.C. 1954. Observations on intercellular canals in root tips with special reference to the Compositae. American Journal of Botany 41:104-106. 